\title{
POULTRY INFECTED WITH Mycoplasma gallisepticum OR Mycoplasma synoviae PRODUCE ANTIBODIES TO THEIR CYSTEINE PROTEASE CYSP
}

\author{
Ivanka CIZELJ ${ }^{1}$, Rebeka Lucijana BERČIČ ${ }^{1}$, Daliborka DUŠANIĆ ${ }^{1}$, Mateja BENČINA ${ }^{1,2}$, \\ Mojca NARAT ${ }^{1}$, Olga ZORMAN-ROJS ${ }^{3}$, Dušan BENČINA ${ }^{1,4}$
}

Received May 15, 2013; accepted June 20, 2013.

Delo je prispelo 15. maja 2013, sprejeto 20. junija 2013.

\begin{abstract}
Poultry infected with Mycoplasma gallisepticum and Mycoplasma synoviae produce antibodies to their cysteine protease CysP

Major poultry pathogens, Mycoplasma gallisepticum and Mycoplasma synoviae possess cysteine protease CysP, which in vitro cleaves chicken immunoglobulin $G$ ( $\operatorname{IgG}$ ) into Fab (antigen-binding fragment) and Fc (crystallisable region fragment). We used recombinant CysP of M. synoviae (rCysP) in enzyme immunoassays to detect antibodies to CysP in sera, synovial fluids, and in washings of respiratory tract and oviducts of chickens and turkeys experimentally or naturally infected with M. gallisepticum or M. synoviae. In poultry infected with M. synoviae, $70.4 \%$ of samples contained antibodies reacting with rCysP. In birds infected with M. gallisepticum we detected CysP antibodies in $63.1 \%$ of samples. Our data demonstrate that CysP is immunogenic for chickens and turkeys and indicate that M. gallisepticum and M. synoviae infecting chickens and turkeys synthesise CysP in vivo. This is the first study demonstrating that proteases of any Mycoplasma species can induce production of specific antibodies in the natural host.
\end{abstract}

Key words: poultry / infections / immunology / immunogenicity / cysteine protease / Mycoplasma synoviae / Mycoplasma gallisepticum

\section{INTRODUCTION}

Among Mycoplasma species infecting poultry, Mycoplasma gallisepticum and Mycoplasma synoviae are the most pathogenic species (Ley 2008; Kleven and Ferguson-Noel, 2008). Although M. gallisepticum and $M$. synoviae belong to different phylogenetic groups, they share hosts, tissue tropism, transmission ways, as well as
Perutnina ob okužbi z bakterijo Mycoplasma gallisepticum ali Mycoplasma synoviae proizvede specifična protitelesa proti njuni cisteinski proteazi CysP

Mycoplasma gallisepticum in Mycoplasma synoviae sta pomembna patogena mikroorganizma pri perutnini. Sintetizirata cisteinsko proteazo CysP, ki in vitro razgrajuje kokošje imunoglobuline $\mathrm{G}$ na Fab in Fc fragment. Za dokazovanje protiteles proti CysP z encimsko imunskimi testi v serumih, sinovialnih tekočinah in $\mathrm{v}$ izpirkih dihalnih traktov in jajcevodov ptic naravno ali eksperimentalno okuženih z M. synoviae ali $M$. gallisepticum, smo uporabili rekombinanten protein CysP (rCysP). Pri perutnini okuženi z M. synoviae je protitelesa proti CysP vsebovalo 70,4 \% vzorcev, pri perutnini okuženi z M. gallisepticum pa smo protitelesa proti CysP dokazali pri 63,1 \% vzorcih. Pridobljeni podatki potrjujejo, da je CysP za perutnino imunogen protein in nakazujejo, da M. gallisepticum in M. synoviae ob okužbi perutnine sintetizirata CysP in vivo. $\mathrm{Z}$ našo študijo prvič dokazujemo, da lahko mikoplazemska proteaza inducira nastanek specifičnih protiteles v naravnem gostitelju.

Ključne besede: perutnina / okužbe / imunologija / imunogenost / cisteinska proteaza / mikoplazme / Mycoplasma synoviae / Mycoplasma gallisepticum

a number of genes that have been transferred horizontally (Noormohammadi et al., 1998; Vasconcelos et al., 2005; Berčič et al., 2011; Cizelj et al., 2011). Among the transferred genes are those encoding proteins being very important in interactions with poultry hosts. M. gallisepticum and $M$. synoviae have multigene families encoding VlhA haemagglutinins, which play important role in binding to host cell receptors and colonization of host

1 Univ. of Ljubljana, Biotechnical Fac., Dept. of Animal Science, Groblje 3, SI-1230 Domžale, Slovenia

2 Univ. of Ljubljana, Fac. of Medicine, Vrazov trg 2, SI-1104 Ljubljana, Slovenia

3 Univ. of Ljubljana, Veterinary Fac., Gerbičeva 60, SI-1000 Ljubljana, Slovenia

4 Corresponding author, e-mail: dusan.bencina@bf.uni-lj.si 
tissues (Noormohammadi et al., 1998; 2000; Benčina 2002). VlhA are immunodominant lipoproteins inducing an early and strong antibody response in poultry (Markham et al., 1992; Narat et al., 1998; Noormohammadi et al., 1999). Chickens infected with M. synoviae at first produced antibodies to the MSPB lipoprotein, which represents the N-terminal part of VlhA (Narat et al., 1998; Noormohammadi et al., 1998; 1999). Moreover, MSPB induced synthesis of nitric oxide (NO), IL $1 \beta$ and IL 6 in chicken peripheral blood leukocytes including macrophages (Lavrič et al., 2007). Recent studies in our laboratories demonstrated that two proteins, shared by $M$. gallisepticum and $M$. synoviae, can modify chicken proteins, including chicken IgG. M. synoviae NanH neuraminidase desialylated chicken IgG and tracheal mucus glycoproteins in vitro (Berčič et al., 2011). Moreover, $M$. gallisepticum and $M$. synoviae cleaved chicken IgG into $\mathrm{Fab}$ and Fc in vitro (Cizelj et al., 2011). Their cysteine protease CysP was involved in this process and recombinant CysP (rCysP) of M. synoviae also cleaved chicken IgG into Fab and Fc (Cizelj et al., 2011) in vitro. Since, CysP has potential to cleave chicken proteins also in vivo, it may be damaging to host during infection. Therefore, we were interested whether infected poultry hosts raise an antibody response against CysP. Indirectly, antibodies to CysP would indicate that M. synoviae and M. gallisepticum populations synthesize CysP in vivo, too.

The aim of this study was to determine whether poultry infected with $M$. synoviae or M. gallisepticum produce antibodies to CysP. For this purpose, rCysP produced in our previous study (Cizelj et al., 2011) was used as a specific antigen with defined structure and a number of samples from infected chickens and turkeys were examined for antibodies to rCysP.

\section{MATERIALS AND METHODS}

\subsection{MYCOPLASMA ANTIGENS, RECOMBINANT CYSP, RECOMBINANT MSPB, PURIFIED PRO- TEINS AND SYNTHETIC PEPTIDES}

M. synoviae WVU 1853 and M. gallisepticum S6 LP strains were used to prepare their whole-cell antigens (Benčina et al., 1994; 2005). Their cells were grown in a modified Frey's broth containing $10 \%$ porcine serum and harvested as described (Berčič et al., 2008a; Dušanić et al., 2009). Recombinant CysP (rCysP) was produced as described in detail in our previous study (Cizelj et al., 2011). Briefly, we introduced eight point mutations replacing eight TGA codons with TGG using site-directed PCR-mediated mutagenesis and added C-terminal His tag in the cysP gene of $M$. synoviae ULB 925. The purified rCysP protein has molecular mass of approximately $67 \mathrm{kDa}$ (Cizelj et al., 2011). A synthetic peptide ${ }_{102}$ DIDEHAIDYVSNS representing immunogenic part of the amino acid sequence of $M$. synoviae and M. gallisepticum CysP and synthetic peptide, ${ }_{464}$ DKRVNNKDDRGHLEQD, representing partial amino sequence of the NanH neuraminidase (Cizelj et al., 2011; Berčič et al., 2011) were purchased from GenWay (San Diego, USA). Recombinant MSPB (rMSPB) containing 190 amino acids of the M. synoviae strain ULB 925 lipoprotein MSPB, the N-terminal part of the haemagglutinin VlhA, was from our previous study (Benčina et al., 2001).

M. gallisepticum (S6 strain) haemagglutinin (previously termed pMGA 1.1) (Markham et al., 1992; 1993) was immuno-affinity purified using mAb 6A10 immobilized to CNBr-sepharose (Sigma) as a specific ligand (Benčina et al., 1994; Miloševič-Berlič et al., 2000). The purified pMGA $(\mathrm{Mw} \sim 67 \mathrm{kDa}$; $\mathrm{pI} \sim 5.5)$ reacted in immunoblots with mAbs 71 to pMGA (Markham et al., 1992), but not with mAb 3 to DnaK (Berčič et al., 2008a) which have in S6 strain similar Mr and pI (Demina et al., 2009).

\subsection{ENZYME IMMUNOASSAYS USED TO DETECT SPECIFIC ANTIBODIES}

Dot-immunobinding assay (DIBA) was used to detect specific antibodies in a variety of samples from poultry infected by M. synoviae or M. gallisepticum. Appropriate antigens were applied as separate dots $(2 \mu \mathrm{l})$ on strips of the Immobilon $\mathrm{P}$ membrane (Millipore) (Benčina et al., 2005). Optimal concentrations of antigens were previously determined by DIBA using reference antibodies to M. synoviae, M. gallisepticum, rCysP, rMSPB, pMGA 1.1 and to synthetic peptides representing partial CysP and NanH (Benčina et al., 1994; 2001; 2005; Berčič et al., 2008a; 2011; Cizelj et al., 2011). So, pelleted mycoplasma cells were diluted in PBS ( $\mathrm{pH}$ 7.4) 1:2000; proteins (rMSPB, rCysP, pMGA) at concentrations of $\sim 5-10 \mu \mathrm{g} / \mathrm{ml}$ and synthetic peptides at a concentration of $\sim 10 \mu \mathrm{g} / \mathrm{ml}$.

DIBA was conducted as a three-step assay. The strips bearing five different antigens (five separate dots, see Fig. 1 and 2) were blocked for $1 \mathrm{~h}$ in PBS containing $0.5 \%$ Tween 20 and then incubated for $1 \mathrm{~h}$ with a sample examined for antibodies or in serum of SPF chicken as negative control. Following washing $(3 \times 15 \mathrm{~min})$ in PBS containing $0.05 \%$ Tween 20 (PBST) strips were incubated for 50 min in PBS containing mAbs CH31 (Sigma) to chicken Igs light chain (see Cizelj et al., 2011). After washing in PBST $(3 \times 15 \mathrm{~min})$ strips were incubated in goat antibodies (to mouse IgG) labeled with horseradish 
peroxidase (HRP, A4416, Sigma) for $45 \mathrm{~min}$. After washing $(2 \times 15 \mathrm{~min}$ in PBST and $15 \mathrm{~min}$ in PBS) reactions were visualized by the chromogen substrate TrueBlue (KPL, USA).

Assays to detect specific IgM or IgA antibodies were done similarly, but on the second step, mAbs M1 to chicken IgM or mAbs A62 to chicken IgA (Benčina et al., 2005) were used instead of $\mathrm{mAbs} \mathrm{CH} 31$.

Most samples were assayed with the two-step DIBA as well. After the first step, performed as described above, strips were incubated in rabbit IgG (to chicken IgG) conjugated with HRP (A9046, Sigma) for 45 min. Following washings, reactions were visualized by TrueBlue. They were evaluated arbitrarily by at least two investigators. In all enzyme immunoassays sera of specific pathogen-free (SPF) chickens were used as negative controls (Benčina et al., 2005). Positive controls were chicken IgG to CysP and NanH peptides (Berčič et al., 2011; Cizelj et al., 2011) and antisera to rMSPB or pMGA (Benčina et al., 2001; Milošević Berlič et al., 2000).

Immunoblotting was used to confirm that samples giving positive DIBA reactions with $\mathrm{rCysP}$ react with this protein $(\sim 67 \mathrm{kDa})$. rCysP $(5 \mu \mathrm{g} / \mathrm{ml})$ was electrophoresed and transferred to the ImmobilonP membrane using the PhastSystem (Pharmacia, LKB, Sweden) and PhastGel Gradient (8-25) gels (Cizelj et al., 2011). Incubations with antibodies and reaction visualization were done as described for DIBA.

The indirect immunoperoxidase assays (IIPA) were used to confirm that samples assayed by DIBA and immunoblotting contain antibodies to M. synoviae (WVU 1853) or M. gallisepticum (S6 or R). Antigens were their intact colonies in situ (on agar blocks) and IIPA was conducted as described elsewhere (Benčina and Bradbury, 1991).

\subsection{SAMPLE COLLECTION, STORAGE AND EX- AMINATIONS}

All samples examined for antibodies to CysP in this study have been collected in our previous experimental studies and examinations of field chicken and turkey flocks for infections with avian Mycoplasma species (see References in Tables 1, 2 and 3). Samples (sera, synovial fluids, mucus from respiratory tract, oviductal washings, exudates from turkey's sinuses) were kept frozen $\left(-20^{\circ} \mathrm{C}\right)$. In DIBA and immunoblotting sera were used diluted 1:100, but some of them were used also at a dilution of 1:1000 or even higher.

Synovial fluids from swollen tibiotarsal-tarsometatarsal (hock) joints, were also assayed diluted 1:100. The same dilution was used for tracheal mucus, whereas res-

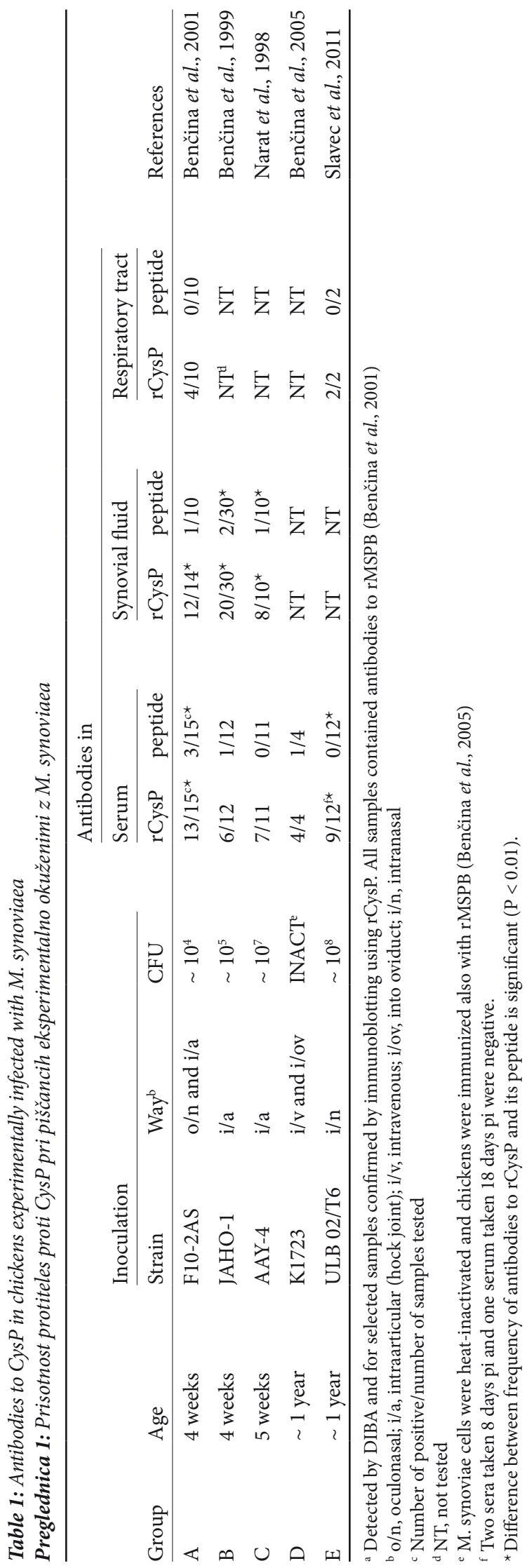

Acta agriculturae Slovenica, 102/1 - 2013 
piratory tract (tracheas, choanal cleft) and oviduct washings were tested considering dilution degree used when they were collected. For such samples total Igs concentrations were first determined by DIBA using mAbs CH31, and then, an appropriate dilution was used in additional assays detecting antibodies to CysP.

\subsection{STATISTICAL ANALYSIS}

Significance of differences between frequencies of antibodies to CysP and to CysP peptide in appropriate samples was determined using two-tailed Fisher's exact test. $\mathrm{P}$ values $<0.01$ were considered significant.

\section{$3 \quad$ RESULTS}

\subsection{EXPERIMENTAL $M$. SYNOVIAE INFECTIONS INDUCED IN CHICKENS ANTIBODIES TO CYSP}

Infections with four different $M$. synoviae strains, using different numbers of CFU and ways of inoculation, induced antibodies to CysP in all four groups of chickens (Table 1). Moreover, antibodies to rCysP were also detected in sera of chickens inoculated with the heat-inactivated M. synoviae K1723. Systemic antibodies to rCysP were detected in 39/54 (72.2\%) of sera, whereas less than $10 \%$ (5/54) of sera contained antibodies to CysP peptide. In chicken groups $\mathrm{A}, \mathrm{B}$ and $\mathrm{C}$ injected with $M$. synoviae intraarticularly, $75.5 \%$ (40/54) of chickens revealed antibodies to rCysP in their synovial fluids, while only $8 \%$ of those fluids had antibodies to CysP peptide. This difference is highly statistically significant $(\mathrm{P}<0.001)$. Chickens of group A inoculated with M. synoviae F10-2AS also oculonasally, had antibodies to rCysP in the upper respiratory tract (choanal cleft) already 8 days post infection. Such antibodies were detected in their synovial fluids and sera 12 days pi (Fig. 1A and Table 1) as well. Antibodies to rCysP present in joints and sera were of the IgM class too and this was found also for antibodies reacting with MSPB (data not shown). In all, antibodies to rCysP were detected in more than $70 \%$ (70.8 \%) of samples tested, whereas those to CysP peptide were found in $8.5 \%$ of samples.
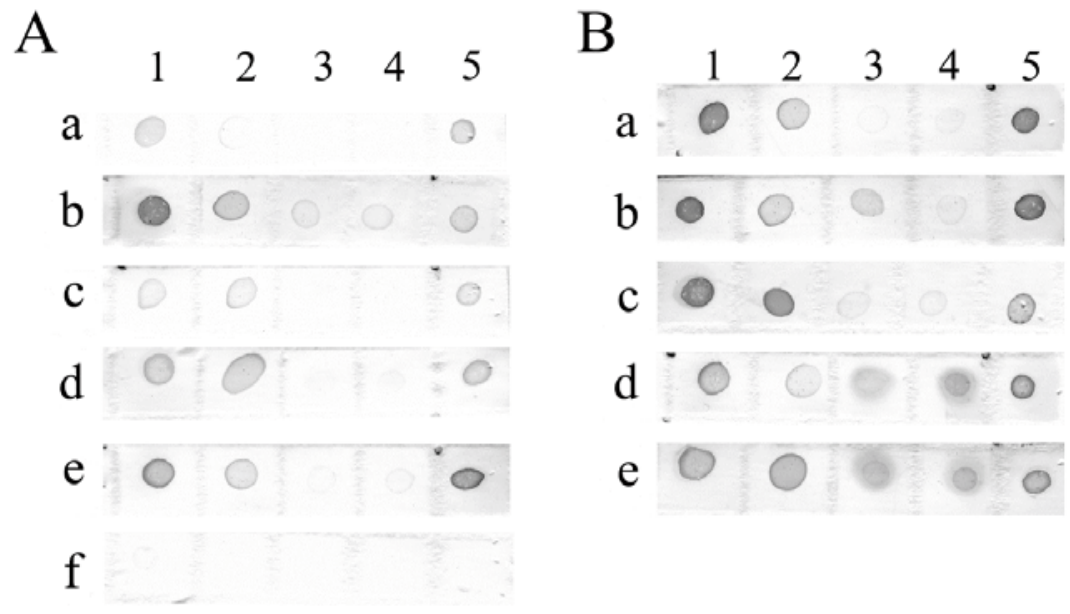

Figure $1(A, B)$ : Antibodies to CysP and MSPB detected by DIBA in M. synoviae infected chickens. Antigens on strips are: 1, M. synoviae WVU 1853 cells; 2, rCysP; 3, CysP peptide; 4, NanH peptide and 5, rMSPB. Strips with antigens were incubated with chicken sera (diluted 1:100) for $1 \mathrm{~h}$ and then with rabbit IgG (to chicken IgG) HRP conjugate for 45 min. Reactions were visualized by TrueBlue. Panel A, reactions with sera of chickens infected experimentally with F10-2AS. Strips a and b, sera of chicken No 1 (taken 8 and 12 days pi); strips $c$ and $d$, sera of chicken No 3 (8 and 12 days pi); strip e, serum of chicken No 4 (12 days pi) and strip $f$, serum of a SPF chicken. Panel B, reactions with sera of naturally infected chickens. Strips $a, b$ and c, sera of chickens from group A; strips $d$ and e, sera of chickens from group B (Table 1). Note, M. synoviae was isolated from tracheas of those naturally infected chickens.

Slika $1(\boldsymbol{A}, \boldsymbol{B})$ : Detekcija protiteles proti CysP in MSPB v vzorcih pǐ̌čancev okuženimi $z$ M. synoviae $z$ DIBA testom. Na trakove naneseni antigeni so: 1, celice M. synoviae WVU 1853; 2, rCysP; 3, peptid CysP; 4, peptid NanH in 5, rMSPB. Slika A, reakcija s serumi piščancev eksperimentalno okuženih z F10-2AS. Trakova a in b, serum piščanca št. 1 (odvzet 8 in 12 dan pi); trakova $c$ in d, serum piščanca št. 3 (odvzet 8 in 12 dan pi); trak e, serum piščanca št. 4 (12 dan pi) in trakf, serum SPF piščanca. Slika B, reakcija s serumi naravno okuženih piščancev. Trakovi $a, b$ in $c$, serumi piščancev iz skupine A; trakova d in e, serumi piščancev iz skupine B (Preglednica 1). Upoštevajte, da je bila iz trahej naravno okuženih piščancev izolirana bakterija M. synoviae. 


\subsection{ANTIBODIES TO CYSP IN M. SYNOVIAE NATURALLY INFECTED CHICKENS AND TURKEYS}

In chickens with the natural M. synoviae infection two thirds of sera $(28 / 42)$ revealed also antibodies to CysP (Fig. 1B and Table 2). Sera from adult hens with the positive M. synoviae culture (tracheas and oviducts), reacted with rCysP also at dilution of 1:1000, one serum even at a dilution of 1:8000. Almost a half of positive sera $(13 / 28)$ contained antibodies reacting with the CysP peptide. The percentage of synovial fluids containing antibodies to rCysP (68.8\%) was rather similar to that of sera (66.7 \%). Synovial fluids contained antibodies to the CysP peptide $(10 / 64)$, but they were detected less frequently than in sera. Antibodies to rCysP were also found in tracheal washings (11/14) and oviduct washings (13/22). As could be expected, antibodies to the CysP peptide were found in those washings less frequently than antibodies to rCysP (Table 2). Differences are statistically significant for synovial fluids (for chicken breeds PPR, ITAL and JA) and respiratory tract samples $(\mathrm{P}<0.01)$.

Synovial fluids collected from swollen hock joints of young (4-8 weeks old) or adult chickens, contained high levels of antibodies to M. synoviae, particularly to its MSPB. Most synovial fluids contained antibodies to CysP of all three classes, IgA, IgG and IgM (detail not shown in Table 2).

In three flocks of turkeys with relatively strong antibody response to $M$. synoviae, almost $80 \%$ of sera (23/30) contained IgG antibodies to rCysP. Moreover, almost $37 \%$ of sera contained antibodies reacting with the CysP peptide (Table 2). Antibodies to rCysP were also found in synovial fluids of some turkeys with acute infectious synovitis due to M. synoviae. Overall, in poultry with natural M. synoviae infection, 127 samples out of $181(70.2 \%)$ samples tested contained antibodies to rCysP.

\subsection{INFECTIONS WITH M. GALLISEPTICUM IN- DUCED ANTIBODIES TO CYSP IN CHICKENS AND TURKEYS}

Adult chickens infected intratracheally with the pathogenic M. gallisepticum strain S6 LP raised antibodies to CysP (Table 3). More than $75 \%$ of sera examined (25/33) contained antibodies reacting with rCysP (Fig. 2). Such antibodies were detected also in tracheal $(14 / 19)$ and in oviduct washings (6/8). Not surprisingly, antibodies to the CysP peptide were less frequent in sera (4/33), tracheal $(2 / 20)$ and oviduct washing (1/8). Antibodies to rCysP were detected in sera of most in-

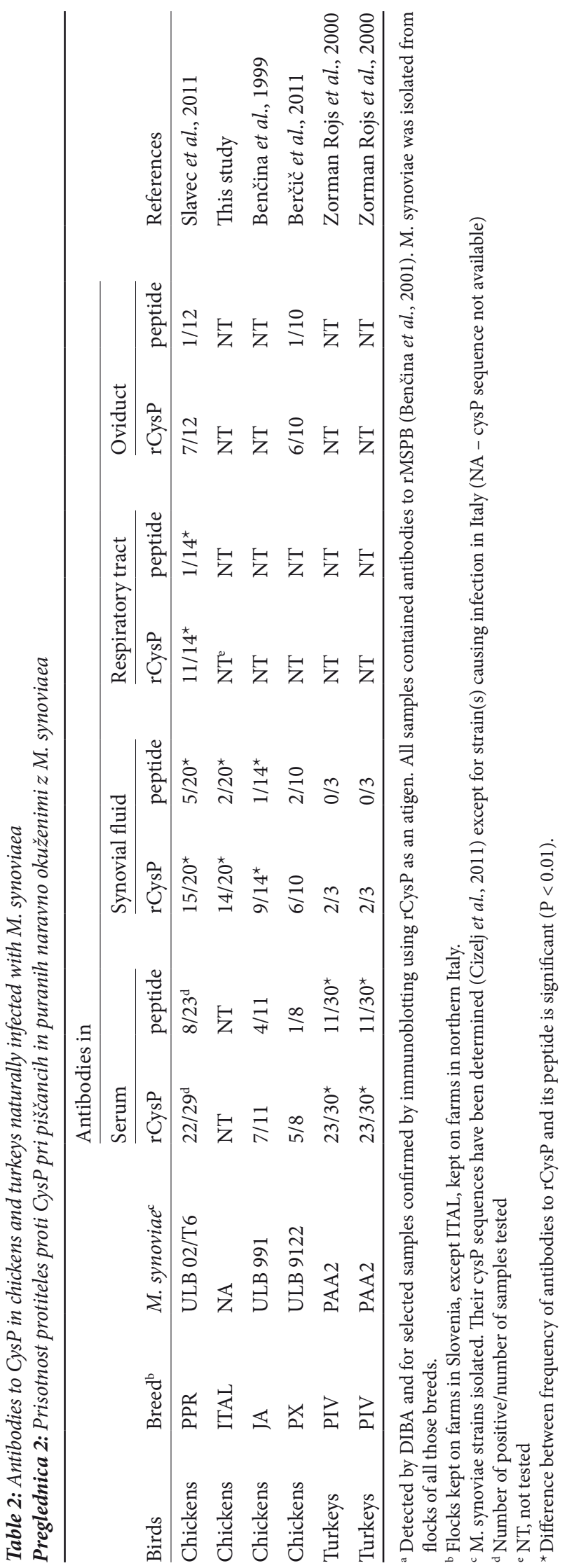

Acta agriculturae Slovenica, 102/1 - 2013 

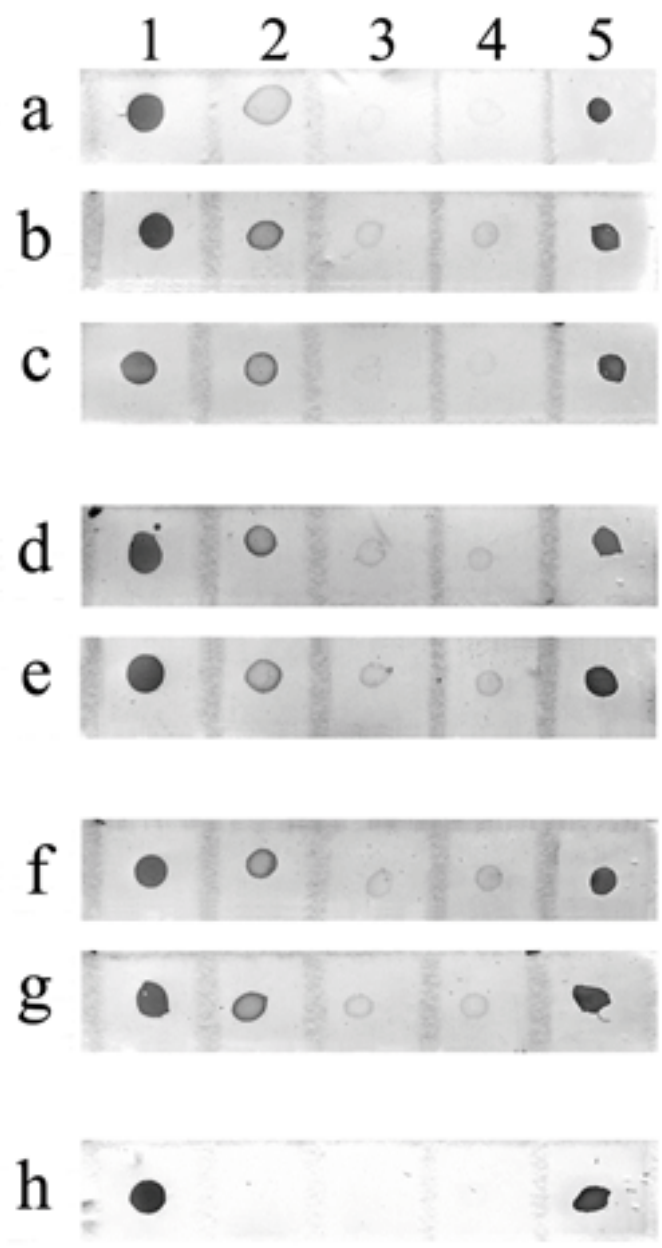

Figure 2: Antibodies to CysP and $p M G A$ detected by DIBA in chickens inoculated with M. gallisepticum (S6 LP). Antigens on strips are: 1, M. gallisepticum (S6 LP) cells; 2, rCysP; 3, CysP peptide; 4, NanH peptide and 5, pMGA. Strips $a, b$ and $c$, sera of three chickens (3 weeks pi); strips $d$ and e, sera of two chickens (6 weeks pi) and strips $f$ and g, sera of two chickens (4 months pi). Strip $h$ was incubated with chicken antiserum to $P M G A$.

Slika 2: Detekcija protiteles proti CysP in pMGA z DIBA testom $v$ vzorcih piščancev, ki smo jim inokulirali M. gallisepticum (S6 LP). Na trakove naneseni antigeni so: 1 , celice M. gallisepticum (S6 LP); 2, rCysP; 3, peptid CysP; 4, peptid NanH in 5, pMGA. Trakov $a, b$ in $c$, serumi treh piščancev (3 tedne pi); trakova d in e, seruma dveh piščancev (6 tednov pi) in trakova fin g, seruma dveh piščancev (4 mesece pi). Trak h smo inkubirali v pMGA specifičnem kokošjem antiserumu.

oculated chickens already 2 weeks pi and also 4 months after infection. Tracheas of contact-exposed chickens became colonized with $M$. gallisepticum 2 weeks after co-habitation with chickens inoculated with S6 LP. After additional 7 days, most of contact-exposed chickens had serum IgM antibodies to the haemagglutinin pMGA, as well as to rCysP (not shown in Table 3). Serum and respiratory tract antibodies to rCysP were detected significantly more frequently than antibodies to CysP peptide (Fisher's exact test, $\mathrm{P}<0.0001$ ). Samples from naturally infected chickens revealed also IgG antibodies to CysP, and they were detectable in sera, respiratory tract and oviduct (Table 3).

Experimental infection of turkeys with $M$. gallisepticum (K4421A) induced antibodies to CysP in their tracheas already 10 days pi (Table 3). Such antibodies were detected in turkeys with the natural M. gallisepticum infection as well. Antibodies to CysP were found in sera and in exudates taken from swollen infraorbital sinuses. In all, in poultry infected with $M$. gallisepticum, 70 samples out of 115 (60.9\%) samples examined contained antibodies to CysP.

\subsection{ANTIBODIES TO CYSP IN PHEASANTS AND PEAFOWL INFECTED WITH M. GALLISEPTI- CUM}

We also examined sera of pheasants and peafowl in which infections with well characterized M. gallisepticum strains ULB 971 and ULB 992 caused severe disease with a considerable mortality (Benčina et al., 2003). Pheasant sera contained IgG antibodies that reacted with both, rCysP and CysP peptide. Sera of peafowl contained antibodies reacting with $\mathrm{rCysP}$, as well as with CysP peptide (not shown in Table 3).

\section{DISCUSSION}

M. gallisepticum and M. synoviae cleave in vitro chicken serum proteins. Among them is IgG, which is cleaved by the CysP protease into Fab and Fc fragments (Cizelj et al., 2011). Considering potential damage caused by CysP to host's proteins, it was of interest to see whether avian hosts infected by M. synoviae or M. gallisepticum raise antibodies to their CysP. Our investigation demonstrates that most of the birds infected by either of the two Mycoplasma spp. produced antibodies to CysP (Tables 1-3). This suggests that M. synoviae and M. gallisepticum produce CysP also in vivo, what apparently triggers host's immune response and the production of specific antibodies. Experimental infections of chickens with $M$. synoviae strains indicated an early antibody response to CysP. Chickens infected with $M$. synoviae F10-2AS had CysP antibodies, including specific IgM, in sera, synovial fluids and upper respiratory tract samples 8 and 12 days pi. In comparison to the antibody response to MSPB, which occurs approximately one week after in- 
fection (Narat et al., 1998; Noormohammadi et al., 1999) response to CysP was not delayed. An early antibody response to CysP was observed also in chickens experimentally infected with the strain S6 LP of M. gallisepticum (Benčina et al., 1994). Interestingly, contact-exposed chickens, whose upper tracheas became colonized with S6 LP in the second week of exposure, had systemic IgM to CysP after 3 weeks of exposure. This suggests that the colonizing M. gallisepticum expressed CysP in conditions simulating natural infection of chickens with M. gallisepticum. In addition, CysP antibodies were present in the upper respiratory tract, along with antibodies to the haemagglutinin pMGA (not shown). Chickens had antibodies to CysP in serum, trachea and oviduct also at the end of the experiment, more than four months pi.

Results shown in Table 2 indicate that CysP is immunogenic for poultry with natural M. synoviae infection. Antibodies to CysP were found in sera, synovial fluids, respiratory tract and oviducts. In most groups antibodies to the CysP peptide were detected too, but less frequently than those to rCysP. This could be expected, because an epitope represented by the synthetic CysP peptide is only one of more than 20 potential epitopes (antigenic sequences) predicted for the $\mathrm{rCysP}$ protein sequence (Larsen et al., 2006). Infections with M. synoviae strains ULB 02/T6 and PAA2 with shorter CysP protein (572 amino acids) induced antibodies to CysP at a similar frequency as strains with longer CysP (ULB 9122, ULB 991) containing 585 amino acids (Cizelj et al., 2011). Turkey flocks presented in Table 2 were co-infected with Ornithobacterium rhinotracheale (Zorman-Rojs et al., 2000). Co-infection did not influence the turkey's antibody response to $M$. synoviae or to its CysP protein, since almost $80 \%$ of sera contained antibodies to CysP (Table 2). Natural infections of chickens and turkeys with M. gallisepticum induced the production of antibodies to its CysP protease (Table 3). This seems to be true also for pheasants and peafowl in which infections with $M$. gallisepticum can be fatal (Benčina et al., 2003). M. gallisepticum induced in poultry antibodies to rCysP less frequently than M. synoviae, but it should be considered that the target antigen used represents CysP of ULB 925 M. synoviae (Cizelj et al., 2011).

The NanH neuraminidase (sialidase), also encoded by a horizontally transferred gene, is associated with invasiveness and virulence of $M$. synoviae and M. gallisepticum strains (May et al., 2007; Berčič et al., 2008b). Polymorphic sequences in the $M$. synoviae strains sialidase proteins indicate diversifying selection (May and Brown, 2009). Notably, polymorphisms in the CysP protease sequences among $M$. synoviae strains also suggest CysP diversifying selection (Cizelj et al., 2011 and unpublished analyses). This study suggests that CysP might be under 
"pressure" of the antibody response, because most of the infected birds produced specific antibodies to CysP (Tables 1-3). At present, this is less clear for the diversifying selection of the $\mathrm{NanH}$ neuraminidase by antibodies to $\mathrm{NanH}$. This study indicates that, poultry infected with $M$. synoviae, raised antibodies to peptide representing $\mathrm{NanH}$ (see Figs. 1B and 2). Antibodies to this peptide were detected even more frequently than antibodies to CysP peptide, but the difference was not statistically significant. Interestingly, CysP and $\mathrm{NanH}$ can modify chicken IgG and target the same region of its heavy chain, albeit with distinct activities. CysP cleaves the heavy chain of IgG in $\mathrm{CH} 2$ domain and generates Fab and Fc (Cizelj et al., 2011). On the other hand, NanH cleaves sialic acid from a $(\mathrm{SAa}(2-6) \mathrm{gal})$ moiety positioned in the N-glycosylated site of $\mathrm{CH} 2$ domain (amino acid $\mathrm{N}_{308}$ ) of the IgG heavy chain (Berčič et al., 2011). The activity of CysP is independent of that of $\mathrm{NanH}$, because $M$. synoviae strains cultures lacking $\mathrm{NanH}$ and neuraminidase activity (Berčič et al., 2011) cleaved chicken IgG (Cizelj et al., 2011).

Our previous analyses suggest that $M$. synoviae grown in vitro can release CysP into growth medium (Cizelj, 2011). If this can happen in vivo, CysP protease would cleave host's proteins including IgG. We observed that in some synovial fluid samples from joints colonized by $M$. synoviae (group A in Table 1), a considerable part of IgG was fragmented into Fab and Fc (Benčina et al., unpublished data). Antibodies to CysP were present, but it is possible that CysP cleaved IgG before antibodies to CysP appeared in synovial fluids. The same synovial fluid samples contained also IgM antibodies reacting with chicken IgG Fc (domains CH3-CH4). Such autoantibodies, termed rheumatoid factor, are frequently present in sera of chickens with infectious synovitis due to $M$. synoviae (Sells, 1976; Porter and Gooderham, 1966). It is possible that $\mathrm{NanH}$ and CysP activities contribute to the induction of autoantibodies to Fc, but further research is needed to confirm this hypothesis.

This study demonstrates that CysP is among crossreactive antigens shared by $M$. gallisepticum and M. synoviae. It is possible that their $\sim 70-\mathrm{kDa}$ proteins sharing antigenic determinants were CysP (Bradley et al., 1988). However, they synthesize a number of other proteins of similar molecular mass and some of them can be crossreactive, too (Berčič et al., 2008a; Benčina et al., unpublished data).

In conclusion, this is the first study demonstrating that hosts can raise antibodies to proteases of Mycoplasma species. Birds infected by M. gallisepticum or M. synoviae produced antibodies to CysP, which is otherwise capable to cause proteolysis of their proteins, including IgG. Whereas antibodies to CysP seem to be incapable to eliminate $M$. synoviae from the respiratory tract, additional investigations are needed to see whether they can diminish damage caused by the CysP proteolytic potential.

\section{ACKNOWLEDGEMENTS}

This work was supported by Slovenian Research Agency (ARRS) (grant P4-0220). We thank Ana Jakopič and Irena Beretič for technical assistance. For donation of materials from M. gallisepticum infected chickens and turkeys, we thank Drs Stanley H. Kleven and Anton Svetlin.

\section{REFERENCES}

Benčina D. 2002. Haemagglutinins of pathogenic avian mycoplasmas. Avian Pathology, 31: 535-547

Benčina D., Bradbury J.M. 1991. Indirect immunoperoxidase assay for the detection of antibody in chicken Mycoplasma infections. Avian Pathology, 20: 113-124

Benčina D., Kleven S.H., Elfaki M.G., Snoj A., Dovč P., Dorrer D., Russ I. 1994. Variable expression of epitopes on the surface of Mycoplasma gallisepticum demonstrated with monoclonal antibodies. Avian Pathology, 23: 19-36

Benčina D., Narat M., Dovč P., Drobnič-Valič M., Habe F., Kleven S.H. 1999. The characterization of Mycoplasma synoviae EF-Tu protein and proteins involved in hemadherence and their N-terminal amino acid sequences. FEMS Microbiology Letters, 173: 85-94

Benčina D., Drobnič-Valič M., Horvat S., Narat M., Kleven S.H., Dovč P. 2001. Molecular basis of the length variation in the N-terminal part of Mycoplasma synoviae hemagglutinin. FEMS Microbiology Letters, 203: 115-123

Benčina D., Mrzel I., Zorman-Rojs O., Bidovec A., Dovč A. 2003. Characterisation of Mycoplasma gallisepticum strains involved in respiratory disease in pheasants and peafowl. Veterinary Record, 152: 230-234

Benčina D., Narat M., Bidovec A., Zorman-Rojs O. 2005. Transfer of maternal immunoglobulins and antibodies to Mycoplasma gallisepticum and Mycoplasma synoviae to the allantoic and amniotic fluid of chicken embryos. Avian Pathology, 34: 463-472

Berčič R.L., Slavec B., Lavrič M., Narat M., Bidovec A., Dovč P., Benčina D. 2008a. Identification of major immunogenic proteins of Mycoplasma synoviae isolates. Veterinary Microbiology, 127: 147-154

Berčič R.L., Slavec B., Lavrič M., Narat M., Zorman-Rojs O., Dovč P., Benčina D. 2008b. A survey of avian Mycoplasma species for neuraminidase enzymatic activity. Veterinary Microbiology, 130: 391-397

Berčič R.L., Cizelj I., Dušanić D., Narat M., Zorman-Rojs O., Dovč P., Benčina D. 2011. Neuraminidase of Mycoplasma synoviae desialylates heavy chain of the chicken immuno- 
globulin G and glycoproteins of chicken tracheal mucus. Avian Pathology, 40: 299-308

Bradley L.D., Snyder D.B., Van Deusen R.A. 1988. Identification of species-specific and interspecies-specific polypeptides of Mycoplasma gallisepticum and Mycoplasma synoviae. American Journal of Veterinary Research, 49: 511-515

Cizelj I. 2011. Identification and characterization of peptidases from Mycoplasma synoviae and Mycoplasma gallisepticum responsible for the cleavage of chicken immunoglobulins. $\mathrm{PhD}$ thesis, Ljubljana, $114 \mathrm{p}$.

Cizelj I., Berčič R.L., Dušanić D., Narat M., Kos J., Dovč P., Benčina D. 2011. Mycoplasma gallisepticum and Mycoplasma synoviae express a cysteine protease CysP, which can cleave chicken IgG into Fab and Fc. Microbiology, 157: $362-372$

Demina I.A., Serebryakova M.V., Ladygina V.G., Rogova M.A., Zgoda V.G., Korzhenevskyi D.A., Govorun V.M. 2009. Proteome of the bacterium Mycoplasma gallisepticum. Biochemistry (Moscow), 74: 165-174

Dušanić D., Berčič R.L., Cizelj I., Salmič S., Narat M., Benčina D. 2009. Mycoplasma synoviae invades non-phagocytic chicken cells in vitro. Veterinary Microbiology, 138: 114-119

Kleven S.H., Fulton R.M., García M., Ikuta V.N., Leiting V.A., Liu T., Ley D.H., Opengart K.N., Rowland G.N., WallnerPendleton E. 2004. Molecular characterization of Mycoplasma gallisepticum isolates from turkeys. Avian Diseases, 48: 562-569

Kleven S.H., Ferguson-Noel N. 2008. Mycoplasma synoviae infection. In: Diseases of Poultry. Saif Y.M., Fadly A.M., Glisson J.R., McDougald L.R., Nolan L.K., Swayne D.E. (eds.). Ames, Iowa, Blackwell Publishing Professional, 12th ed.: 845-856

Lavrič M., Benčina D., Kothlow S., Kaspers B., Narat M. 2007. Mycoplasma synoviae lipoprotein MSPB, the N-terminal part of VlhA haemagglutinin, induces secretion of nitric oxide, IL- 6 and IL- $1 \beta$ in chicken macrophages. Veterinary Microbiology, 121: 278-287

Larsen J.E., Lund O., Nielsen M. 2006. Improved method for predicting linear B-cell epitopes. Immunome Research, 2: 2

Ley D.L. 2008. Mycoplasma gallisepticum infection. In: Diseases of Poultry. Saif Y.M., Fadly A.M., Glisson J.R., McDougald L.R., Nolan L.K., Swayne D.E. (eds.). Ames, Iowa, Blackwell Publishing Professional, 12th ed.: 807-834

Markham P.F., Glew M.D., Brandon M.R., Walker I.D., Whithear K.G. 1992. Characterization of a major hemagglutinin protein from Mycoplasma gallisepticum. Infection and Immunity, 60: 3885-3891

Markham P.F., Glew M.D., Whithear K.G., Walker I.D. 1993. Molecular cloning of a member of the gene family that encodes pMGA, a hemagglutinin of Mycoplasma gallisepticum. Infection and Immunity, 61: 903-909

May M., Brown D.R. 2009. Diversifying and stabilizing selection of sialidase and $\mathrm{N}$-acetylneuraminate catabolism in Mycoplasma synoviae. Journal of Bacteriology, 191: 3588-3593

May M., Kleven S.H., Brown D.R. 2007. Sialidase activity in Mycoplasma synoviae. Avian Disease, 51: 829-833

Milošević Berlič T., Benčina D., Dovč P. 2000. Sequence poly- morphisms within the pMGA genes and pMGA antigenic variants in Mycoplasma gallisepticum. FEMS Microbiology Letters, 184: 133-139

Narat M., Benčina D., Kleven S.H., Habe F. 1998. The hemagglutination positive phynotype of Mycoplasma synoviae induces experimental infetious synovitis in chicken more frequently than the hemagglutination-negative phynotype. Infection and Immunity, 66: 6004-6009

Noormohammadi A.H., Markham P.F., Duffy M.F., Whithear K.G., Browning G.F. 1998. Multigene families encoding the major hemagglutinins in phylogenetically distinct mycoplasmas. Infection and Immunity, 66: 3470-3475

Noormohammadi A.H., Markham P.F., Markham J.F., Whithear K.G., Browning G.F. 1999. Mycoplasma synoviae surface protein MSPB as a recombinant antigen in an indirect ELISA. Microbiology, 145: 2087-2094

Noormohammadi A.H., Markham P.F., Kanci A., Whithear K.G., Browninig G.F. 2000. A novel mechanism for control of antigenetic variation in the hemagglutinin gene family of Mycoplasma synoviae. Molecular Microbiology, 35: 911-923

Porter P., Gooderham K.R. 1966. Changes in serum proteins and identification of a rheumatoid factor in a field outbreak of avian infectious synovitis. Research in Veterinary Science, $7: 25-34$

Sells D.M. 1976. Progressive changes in serum proteins and the rheumatoid factor of chickens infected with M. synoviae. Avian Disease, 20: 108-117

Slavec B, Berčič R.L., Cizelj I., Narat M., Zorman-Rojs O., Dovč P., Benčina D., 2011. Variation of vlhA gene in Mycoplasma synoviae clones isolated from chicken. Avian Pathology, 40: 481-489

Vasconcelos A.T., Ferreira H.B., Bizarro C.V., Bonatto S.L., Carvalho M.O., Pinto P.M., Almeida D.F., Almeida L.G., Almeida R., Alves-Filho L., Assuncao E.N., Azevedo V.A., Bogo M.R., Brigido M.M., Brocchi M., Burity H.A., Camargo A.A., Camargo S.S., Carepo M.S., Carraro D.M., de Mattos Cascardo J.C., Castro L.A., Cavalcanti G., Chemale G., Collevatti R.G., Cunha C.W., Dallagiovanna B., Dambros B.P., Dellagostin O.A., Falcao C., Fantinatti-Garboggini F., Felipe M.S., Fiorentin L., Franco G.R., Freita, N.S., Frias D., Grangeiro T.B., Grisard E.C., Guimaraes C.T., Hungria M., Jardim S.N., Krieger M.A., Laurino J.P., Lima L.F., Lopes M.I., Loreto E.L., Madeira H.M., Manfio G.P., Maranhao A.Q., Martinkovics C.T., Medeiros S.R., Moreira M.A., Neiva M., Ramalho-Neto C.E., Nicolas M.F., Oliveira S.C., Paixao R.F., Pedrosa F.O., Pena S.D., Pereira M., PereiraFerrari L., Piffer I., Pinto L.S., Potrich D.P., Salim A.C., Santos F.R., Schmitt R., Schneider M.P., Schrank A., Schrank I.S., Schuck A.F., Seuanez H.N., Silva D.W., Silva R., Silva S.C., Soares C. M., Souza K.R., Souza R.C., Staats C.C., Steffens M.B., Teixeira S.M., Urmenyi T.P., Vainstein M.H., Zuccherato L.W., Simpson A.J., Zaha A. 2005. Swine and poultry pathogens: the complete genome sequences of two strains of Mycoplasma hyopneumoniae and a strain of Mycoplasma synoviae. Journal of Bacteriology, 187: 5568-5577

Zorman-Rojs O., Zdovc I., Benčina D., Mrzel I. 2000. Infection of turkeys with Ornithobacterium rhinotracheale and Mycoplasma synoviae. Avian Disease, 44: 1017-1022 